\title{
Placenta accreta: the silent invader
}

\section{Seema Dwivedi*, Gopaal Narayan Dwivedi, Archana Kumar, Neena Gupta, Vinita Malhotra, Neha Singh}

Department of Obstetrics and Gynaecology, GSVM Medical College, Kanpur University, Kanpur, UP, India

\author{
Received: 26 February 2016 \\ Revised: 02 April 2016 \\ Accepted: 07 April 2016

\section{* Correspondence:} \\ Dr. Seema Dwivedi, \\ E-mail: seema993573@gmail.com
}

Copyright: (c) the author(s), publisher and licensee Medip Academy. This is an open-access article distributed under the terms of the Creative Commons Attribution Non-Commercial License, which permits unrestricted non-commercial use, distribution, and reproduction in any medium, provided the original work is properly cited.

\begin{abstract}
Background: To review incidence causes, clinical presentations, management, maternal mortality and morbidity associated with placenta accreta.

Methods: A prospective study was carried out at the Department of Obstetrics and Gynaecology, GSVM Medical College, Kanpur during the period of January 2010 to December 2014. During this period all the patients who were diagnosed with placenta accreta were included in the study.

Results: Majority of patients presenting with placenta accreta belonged to age group 30-35 years (46\%) were multigravida (95\%) came from both rural and urban background. Majority of deliveries complicated by placenta accrete were booked cases (78\%). Previous LSCS with placenta previa proved to be the major cause (86\%). Out of whole spectrum including placenta accreta, increta, percreta, placenta accreta was the commonest of all and placenta percreta required maximum number of blood transfusions (5-6 units of blood on an average). Hysterectomy was required in 29 cases out of 37 (78\%), 6 women suffered from bladder injury which were repaired. Among total of 37 women 7women couldn't be saved even after our best of efforts.

Conclusions: Incidence of placenta accrete has increased now a days because of increased incidence of cesarian sections, placenta accreta was seen in primi due to uterine procedures done deliberately in both diagnostic and therapeutic indications. Morbidly adherent placenta is always a nightmare for the obstetrician. Suspicion of a case on history, preoperative confirmation of diagnosis, planned management with bundle of care, with multi-disciplinary approach can save many patients from the clutches of inevitable death.
\end{abstract}

Keywords: Placenta accreta, Cesarian

\section{INTRODUCTION}

Normal placentation occurs from the adherence of blastocyst to the decidualised endometrium. Abnormal placenta includes placenta previa, abruptio placentae, caesarian scar, ectopic pregnancy, cervical pregnancy and the accreta spectrum. Placenta accreta occurs secondary to abnormal adherence of placenta to the myometrium instead of decidua. This abnormal adherence has important clinical implications that can result in severe maternal and fetal morbidity and mortality. This typically occurs when placenta does not separate from the uterus after delivery, leading to massive haemorrhage and associated complications such as disseminated intravascular coagulations, multi organ dysfunction and / or failure and death. ${ }^{1}$.

Correction and treatment of haemorrhage often required massive transfusion, intensive care-unit, admission, interventional radiological procedures and hysterectomy, fetal morbidity as well as mortality is related to premature births. $^{2}$

With the increased recognition of risk factors and obstetric ultrasonography, many cases of placenta accreta disorders are diagnosed prenatally. However, not all have access to ultrasound, qualified ultra-sonographers or experienced radiologists or obstetricians, who can make 
this diagnosis antenatally. Because of all these limitations placenta increta, accreta and percreta may be diagnosed at the time of delivery. It is therefore important for obstetrician and other providers of obstetric care to be familiar, be suspicious and aware of all its aspects and management of potentially high morbid and fatal disorders of abnormal placentation.

This study was conducted to review incidence, causes, clinical presentations management, maternal mortality and morbidity associated with placenta accreta.

Ideally suspected accreta cases should be referred to higher centres of excellence for management.

\section{METHODS}

All the women diagnosed with placenta accreta were included in the prospective study during the period of January 2010 to December 2014, carried out in UISEMH GSVM Medical College Kanpur.

Only few cases were diagnosed in $1^{\text {st }}$ and $2^{\text {nd }}$ trimester, majority were diagnosed in $3^{\text {rd }}$ trimester. In $1^{\text {st }}$ and $2^{\text {nd }}$ trimester, suspicion of placenta accreta included, low lying, and gestational sac attached to anterior wall of uterus, thin myometrium, irregular vascular sinuses or turbulent flow within. Of all ultrasonographic findings, turbulent flow and the presence of lacunae were most consistently associated with accreta.

No antenatal diagnostic technique affords $100 \%$ assurance of either ruling in or ruling out the presence of placenta accreta. Definitive diagnosis was made post partum in cases of hysterectomy where specimens showed chorionic villi in direct contact with the myometrium and absence of decidua. Patients prenatally suspected of placenta accreta were counselled extensively about potential risks and complications well in advance of their estimated due date, discussions involved likelihood of hysterectomy and subsequent infertility.

In patients with strong suspicion for placenta accreta, delivery was conducted before haemorrhage occurred, with use of corticosteroids for lungs maturation for preterm cases.

Patients who came with antepartum haemorrhage with active bleed were instantly shifted for caesarean section irrespective of their gestational age.

Choice of anaesthesia remains controversial and in the hands of anaesthesiologist on call. General anaesthesia was preferred in low patients who were actively bleeding, were severely anaemic and abnormal placentation was highly expected. Adequate arrangement of blood and ICU was kept ready.

\section{RESULTS}

Table 1: Demographic profile.

\begin{tabular}{|c|c|c|}
\hline Parameter & No. of patients & $\%$ \\
\hline \multicolumn{3}{|l|}{ Age } \\
\hline $20-25$ yrs & 3 & 8 \\
\hline $25-30 \mathrm{yrs}$ & 7 & 19 \\
\hline $30-35$ yrs & 17 & 46 \\
\hline $35-40$ yrs & 10 & 27 \\
\hline \multicolumn{3}{|l|}{ Parity } \\
\hline primi & 2 & 5 \\
\hline multi & 14 [p2] & 95 \\
\hline multi & $21[\mathrm{p} 3]$ & \\
\hline \multicolumn{3}{|l|}{ Socio economic status } \\
\hline Rural & 18 & 49 \\
\hline Urban & 19 & 51 \\
\hline \multicolumn{3}{|l|}{ Admission } \\
\hline Booked & 29 & 78 \\
\hline Unbooked & 08 & 22 \\
\hline
\end{tabular}

Table 2: Causes of placenta accreta.

\begin{tabular}{|lll|}
\hline Causes & No of patients & $\%$ \\
\hline Previous LSCS & $\begin{array}{l}\text { 32(25 Previous1LSCS) } \\
\text { (7 Previous 2LSCS) }\end{array}$ & $\begin{array}{l}86(67, \\
19)\end{array}$ \\
\hline $\begin{array}{l}\text { Previous D and } \\
\text { C/MTP }\end{array}$ & 15 & 29 \\
\hline $\begin{array}{l}\text { Previous } \\
\text { Endometritis }\end{array}$ & 5 & 10 \\
\hline Placenta Previa & 31 & 83 \\
\hline
\end{tabular}

Table 3: Presenting complaints.

\begin{tabular}{|lll|}
\hline Complaints & No. of patients & $\%$ \\
\hline No complaints & 8 & $21 \%$ \\
\hline Antepartum haemorrhage & 18 & $48 \%$ \\
\hline Post-partum haemorrhage & 5 & $13 \%$ \\
\hline Retained placenta & 5 & $13 \%$ \\
\hline Inversion of uterus & 1 & $2 \%$ \\
\hline
\end{tabular}

Table 4: Diagnosis of accreta.

\begin{tabular}{|lll|}
\hline & No of patients & $\%$ \\
\hline Antenatal (USG) & 26 & 70 \\
\hline Perop & 07 & 19 \\
\hline Post delivery & 04 & 11 \\
\hline
\end{tabular}

Table 5: Trimester wise diagnosis of placenta accreta patients.

\begin{tabular}{|lll|}
\hline Trimester & No of patients & Percentage \\
\hline $1^{\text {st }}$ & 3 & 8 \\
\hline $2^{\text {nd }}$ & 4 & 10 \\
\hline $3^{\text {rd }}$ & 30 & 81 \\
\hline
\end{tabular}

Majority of patients presenting with placenta accreta belonged to age group 30-35 years (46\%) were multigravida $(95 \%)$ came from both rural and urban background. Majority of deliveries complicated by 
placenta accrete were booked cases (78\%). Previous LSCS with placenta previa proved to be the major cause $(86 \%)$. Out of whole spectrum including placenta accreta, increta, percreta, and placenta accreta was the commonest of all and placenta percreta required maximum number of blood transfusions (5-6 units of blood on an average). Hysterectomy was required in 29 cases out of 37 (78\%), 6 women suffered from bladder injury which were repaired. Among total of 37 women 7women couldn't be saved even after our best of efforts.

Table 6: Placenta localisation by ultrasound.

\begin{tabular}{|l|l|l|}
\hline Diagnosis & No of patients & $\%$ \\
\hline Confirmed by USG & 26 & 70 \\
\hline Missed by USG & 3 & 8 \\
\hline Anterior Placenta & 13 & 35 \\
\hline Posterior Placenta & 3 & 8 \\
\hline Central Placenta Previa & 21 & 56 \\
\hline
\end{tabular}

Table 7: Types of adherent placenta and requirement of blood.

\begin{tabular}{|llll|}
\hline $\begin{array}{l}\text { Type of } \\
\text { placenta }\end{array}$ & $\begin{array}{l}\text { No of } \\
\text { patients }\end{array}$ & $\%$ & $\begin{array}{l}\text { Requirement } \\
\text { of blood } \\
\text { transfusion }\end{array}$ \\
\hline $\begin{array}{l}\text { Placenta } \\
\text { accreta }\end{array}$ & 14 & 37 & $2-3$ \\
\hline $\begin{array}{l}\text { Placenta } \\
\text { increta }\end{array}$ & 10 & 27 & $3-4$ \\
\hline $\begin{array}{l}\text { Placenta } \\
\text { percreta }\end{array}$ & 07 & 19 & $5-6$ \\
\hline $\begin{array}{l}\text { Adherent } \\
\text { lobule of } \\
\text { placenta }\end{array}$ & 04 & 16 & 01 \\
\hline
\end{tabular}

Table 8: Management done.

\begin{tabular}{|lll|}
\hline Management & No of patients & $\%$ \\
\hline Hysterectomy & 29 & 78 \\
\hline Placental retention & 06 & 17 \\
\hline Methotrexate & 02 & 05 \\
\hline
\end{tabular}

\section{DISCUSSION}

The rate of cesarean delivery has increased sustantially over the past few decades. ${ }^{5,6}$ As the caesarean rate increased, so has the incidence complicated by placenta accreta spectrum disorders. ${ }^{7,9}$ Multiple studies support the substantially increased risk of placenta accreta in woman with a history of multiple cesarean deliveries.

The majority of placenta accreta occur in multiparous woman, especially in those with at least 1 prior cesarean delivery. As the number of prior caesarean increases so does risk of encountering a placenta accreta, increta or percreta. ${ }^{7}$ The presence of a placenta previa and history of multiple caesareans increase drastically the risk of abnormal placentation involving a previous caesarean scar. ${ }^{7}$
Table 9: Outcomes in terms of maternal morbidity and mortality.

\begin{tabular}{|lll|}
\hline Outcome & No of patients & $\%$ \\
\hline PPH & 32 & 86 \\
\hline Haemorrhagic shock & 16 & 43 \\
\hline Bladder injury & 6 & 16 \\
\hline Sepsis & 5 & 13 \\
\hline DIC & 1 & 2 \\
\hline No Complications & 9 & 24 \\
\hline Referred to ICU & 8 & 21 \\
\hline Death & 7 & 18 \\
\hline
\end{tabular}

In our study majority of patients were multiparous coming from both urban and rural setup, having history of previous LSCS as a common risk factor and antepartum hemorrhage as the most common presenting symptom (Table 1-3).

The gold standard of diagnosis continues to be histologic examination of the placenta and uterus with documentation of abnormal trophoblast invasion of the myometrium. However this is only possible when a hysterectomy is performed. Accreta is considered to be present when the placenta is abnormally adherent. ${ }^{10}$

Ultrasound findings suggestive of accreta can vary and depend on gestational age and placental development. In the first trimester, a finding of a gestational sac implanted low anterior in the uterus along with loss of retro placental - myometrial zone can also potentially be seen. ${ }^{11-13}$ The most helpful finding on USG is to identify the presence of placenta previa showing a complete loss of disruption of myometrial continuity .Placenta accreta seems to be irregular secondary to lacunae giving the placenta a Swiss cheese appearance. Doppler velocimetry often detects a lacunar turbulence. ${ }^{14,15}$ In our study maximum patients of accreta $81 \%$ were diagnosed antenatally in $3^{\text {rd }}$ trimester (Table 4 and 5). $83 \%$ patients had placenta previa (Table 6).

In our study of all the ultrasonographic findings, turbulent flow and the presence of lacunae were most consistenly associated with accreta. Prenatal diagnosis provided multiple advantages for the management of a pregnancy complicated by placenta accreta. First delivery without attempting to remove the placenta decreases blood loss significantly, and is accomplished by making a vertical classical hysterectomy away from the placentas. $^{16,17}$ Rarely hysterectomy is deferred in the hopes of conserving the uterus and hence the fertility. ${ }^{18}$

In our study timing of delivery was individualized based on several factors including, PROM, labour, bleeding and suspicion of percreta. We scheduled delivery between 34 and 36 week of gestation, based on the stability of the clinical course. Majority of patients in our study (78\%). under went hysterectomy as about $27 \%$ had placenta increta and $19 \%$ had placenta percreta with four cases 
showing bladder invasion. Of the $17 \%$ patients managed conservatively, one patient with placenta in situ died due to sepsis (Table 7 and 8). Blood transfusion was required in more than $80 \%$ cases at least one half required 4 or more units of packed red blood cells. There was a mean blood loss of 2 litres (Table 7).

Despite scheduled delivery in a well-resourced setting with highly experienced and adequately prepared multidisciplinary team, significant complications can occur. The most common are massive and/or persistent hemorrhage, cystotomy ureteral damage and bowel injury These complications often result in ICU admission (25\%$50 \%$ of cases). ${ }^{19}$

Similarly in our study $86 \%$ of the patients suffered from postpartum hemorrhage with $43 \%$ landing in haemorrhagic shock. Sepsis was more common in cases of conservative management and $21 \%$ patients were transferred to ICU (Table 9).

Whether from placental invasion into the bladder, unintentional injury owing to improved visualization and poor dissection planes, or intentional injury (to facilitate visualisation), cystotomy is the most common, surgical complication in the management of accreta; one review identified the risk as high as $17 \%$. Similar to the bladder injury rate of $16 \%$ in our study.

Maternal mortality in our study was $18 \%$, of the seven lives lost; three patients were referred in a exsanguinated state with irreversible shock. Rest of the mortalities occurred when the diagnosis was made per op, the patients being shifted for antepartum hemorrhage and by the time seniors could take over, patient died due to massive hemorrhage (Table 9).

\section{CONCLUSION}

As the incidence of caesarean have increased, placenta accreta also has increased and is an important cause of maternal and fetal/neonatal morbidity and mortality. Although multiple caesarean deliveries are the largest risk factor for placenta accreta, previa, increasing maternal age and parity, as well as other uterine surgeries are also important. In patient at risk for accreta, obstetrical ultrasonography performed by an experienced provider should be obtained. A multidisciplinary team in a center with expertise in managing placenta accreta should care for cases of suspected accreta.

\section{Funding: Not required}

Conflict of interest: None declared

Ethical approval: The study was approved by the Institutional Ethics Committee

\section{REFERENCES}

1. Upson K, Silver RM, Greene R. Placenta accreta and maternal morbidity in the Republic of ireland, 2005-
2010. J Matern Fetal Neonatal Med. 2014:27(1):249.

2. Inograd A, Waistock T, Mazor M. Placenta accereta is an independent risk factor for late pre-term birth and perinatal mortality. J Matern Fatel Neonatal Med. 2014;1-7.

3. Palacious Jaraquemada JM. Diagnosis and management of placenta accreta Best Pract Res Clin Obstet Gynaeol. 2008;22(6):1133-48.

4. Garmi G, Salim R. Epidemiology, etiolopgy, diagnosis, and management of placenta accreta. Obstet Gyneol Int. 2012;2012(8):873929.

5. MacDorman MF Manacker F, Declercq E. Cesarean birth in the United States: epidemiology, trends, and outcomes. Clin Perinatol. 2008:35(2):293-307.

6. Khong TY. The Pathology of placenta accreta, a worldwide epidemic. J Clin Pathology. 2008;61(12):1243-6.

7. Silver RM, London MB, Rouse DJ, et al. Maternal morbidity associated with multiple repeat cesarean deliveries. Obstet Gynecol. 2006;107(6):1226-32.

8. Silver RM. Implication of the first cesarean: Perinatal and future reproductive health and subsequent cesareans. placentation issues, uterine rupture risk, morbidity and mortality. cesareans, placentation issue, uterine rupture risk morbidity, and mortality. Semin Perinatol. 2012;36(5);315-23.

9. Gyamfi-Bannerman C, Gilbert S, LOndon MB. Risk of uterine rupture and placenta accreta with prior uterine surgery outside of the lower segment. Obutet Gyecol. 2012;120(6):1332-7.

10. Belfort MA. Placenta accreta. A J Gynecol. 2010:203(5):430-9.

11. Comstock CH, Bronsteen RA. The antenatal diagnosis of placenta accreta. BJOG. 2014:121(2):171-81.

12. Chen YJ, Wang PH, LIu WM. Placeta accreta diagnosed at 9 weeks' gestation. Ultrasound Obstet Gynol. 2002;19(6):620-2.

13. Morettin F, Merziotis M, Ferraro ZM. The importance of a last first trimester placental sonogram in patients at risk of abnormal placentation.Case ep Obstet Gynecol. 2014;2014(9):345348.

14. Chou MM, Ho ES, Lee YH. Prenatal diagnosis of placenta previa accreta by transabdominal colour Doppler ultrasound. Ultrasoud Obstet Gynol. 2001;17(1):28-35.

15. Chou MM, Tseng JJ, Hwang J1. Sonographic appearance of tornado blood flow in placenta previa accreta/increta. Ultrasound Obstet Gynol. 2001;17(4):362-3.

16. Eller AG, Porter TF, Soisson P. Optimal management strategies for placenta accreta. BJOG. 2009;116(5):648-54.

17. Warshak CR, Ramos GA, Eskandar R. Effect of predelivery diagnosis in 99 consecutive cases of placenta accreta Obstet Gynol. 2010;115(1):65-9.

18. Fizpatrick Ke, Seller S, Spark P. The management and outcomes of placenta accreta, increta, and 
percreta in the UK: a population-based descriptive study. BJOG. 2014;121(1):62-70.
19. Bretalle F, Courbiere B, Mazouni C. Management of placenta accreta. morbidity and outcomes.Eur J Obstet Gynol Reprod Biol. 2007;133(1):34-9.

Cite this article as: Dwivedi S, Dwivedi GN, Kumar A, Gupta N, Malhotra V, Singh N. Placenta accreta: the silent invader. Int J Reprod Contracept Obstet Gynecol 2016;5:1501-5. 